\title{
Is There Still Bullying in Medicine at All Levels - Undergraduate and Postgraduate? [Response to Letter]
}

This article was published in the following Dove Press journal:

Advances in Medical Education and Practice

\author{
Simon D Taylor-Robinson (D) \\ Paulo Alberto De Souza Lopes ${ }^{2}$ \\ Jey Zdravkov ${ }^{3}$ \\ Rachel Harrison (iD) ${ }^{4}$ \\ 'Department of Surgery and Cancer, \\ Imperial College London, London, UK; \\ ${ }^{2}$ Department of Medicine, UAI \\ Universidad Abierta Interamericana, \\ Buenos Aires, Argentina; ${ }^{3}$ Dean Street \\ Sexual Health Clinic, London, UK; \\ ${ }^{4}$ Department of South East Asian Studies, \\ School of Oriental and African Studies, \\ London, UK
}

\section{Dear editor}

We thank Sharma and her co-authors for their very insightful comments on our perspective on bullying in Medicine. ${ }^{1,2}$

We completely agree with them that bullying has been an issue at all stages in the medical career pathway, including at an undergraduate level. ${ }^{1}$ We agree also that to be fully comprehensive, discussion of the medical student experience should have been included, but our article went through several journals before it was accepted and the advice consistently given was to concentrate on the specific experience of our "reportee".

To this end, we did not specifically cover the medical student experience, because our report was written as a "personal perspective" of direct conversations that were had with a senior medical academic, who chose to share his experiences only as a qualified doctor and who did not talk about his experiences as a medical student. $^{2}$ However, in our article, we did reference two studies from 2015 and 2020 which clearly demonstrate that bullying is something experienced very widely at the undergraduate level by a large proportion of medical students, as Sharma and co-authors have otherwise noted. ${ }^{3,4}$

We note and welcome the safeguarding changes made to the undergraduate experience in many countries highlighted by Sharma and her co-authors, in the creation of both personal and pastoral tutors to provide pathways to channel concerns and difficulties on all aspects of medical student welfare, including bullying. ${ }^{5}$

We maintain that bullying of whatever form should have no place in the Medical Profession and agree with Sharma and her co-authors that this must also involve medical student education. There can be no room for teaching by humiliation. ${ }^{3}$

We apologise if there has been any misunderstanding, but with respect to institutionalised bullying, we did not intend to be critical of centralised monitoring systems, such as Athena SWAN in the United Kingdom, which are designed to reward academic and medical institutions for positive steps to introduce equality and mitigate bullying. ${ }^{6}$ However, there is heavy emphasis on the reports generated by the institutions themselves, which in our opinion may be written to show them off in the best light. We were merely suggesting that allowing a greater emphasis on individual viewpoints (perhaps anonymised), may facilitate a channel for real life 
experience to be acknowledged and in so doing, bringing a 360 degree experience to the thought process on eliminating the problem from the profession. We hoped to open up a debate on the issue and are grateful to Sharma and her co-authors for their thoughtful comments.

\section{Acknowledgments}

We are grateful to colleagues from a variety of institutions: Drs Jay Watts, Michael Fertleman, Steven Di Costa and Munira Alsaleh; Mr Aditya Agrawal, Mr JJ Çiyiltepe, Mrs Orli Rhodes-Kendler and the still academically active father of SDT-R for their comments and shared experiences. SDT-R is grateful to the United Kingdom National Institute for Healthcare Research at Imperial College London for infrastructure support and the Wellcome Trust Institutional Strategic Support Fund for funding.

\section{Disclosure}

The authors report no conflicts of interest in this communication.

\section{References}

1. Sharma S, Patel N, Krasniqi L. A response to "A personal perspective: is bullying still a problem in medicine?" - a medical student perspective. Adv Med Educ Pract. 2021.

2. Taylor-Robinson SD, De Sousa Lopes PA, Zdravkov J, Harrison R. A personal perspective: is bullying still a problem in medicine? $A d v$ Med Educ Pract. 2021;12:141-145. doi:10.2147/AMEP.S297835

3. Scott KM, Caldwell PH, Barnes EH, Barrett J. "Teaching by humiliation" and mistreatment of medical students in clinical rotations: a pilot study. Med J Aust. 2015;203(4):185e.1-6. PMID: 26268289. doi:10.5694/mja15.00189.

4. Colenbrander L, Causer L, Haire B. 'If you can't make it, you're not tough enough to do medicine': a qualitative study of Sydney-based medical students' experiences of bullying and harassment in clinical settings. BMC Med Educ. 2020;20(1):86. PMID: 32209074; PMCID: PMC7092452. doi:10.1186/s12909-020-02001-y.

5. Gamble Blakey A, Smith-Han K, Anderson L, Collins E, Berryman E, Wilkinson TJ. Interventions addressing student bullying in the clinical workplace: a narrative review. BMC Med Educ. 2019;19(1):220. doi:10.1186/s12909-019-1578-y

6. Kalpazidou Schmidt E, Ovseiko PV, Henderson LR, Kiparoglou V. Understanding the Athena SWAN award scheme for gender based equality as a complex social intervention in a complex system: analysis if Silver award action plans in a comparative European perspective. Health Res Policy Syst. 2020;18:19. doi:10.1186/s12961-020-0527-x

Dove Medical Press encourages responsible, free and frank academic debate. The content of the Advances in Medical Education and Practice 'letters to the editor' section does not necessarily represent the views of Dove Medical Press, its officers, agents, employees, related entities or the Advances in Medical Education and Practice editors. While all reasonable steps have been taken to confirm the content of each letter, Dove Medical Press accepts no liability in respect of the content of any letter, nor is it responsible for the content and accuracy of any letter to the editor.

\section{Publish your work in this journal}

Advances in Medical Education and Practice is an international, peerreviewed, open access journal that aims to present and publish research on Medical Education covering medical, dental, nursing and allied health care professional education. The journal covers undergraduate education, postgraduate training and continuing medical education including emerging trends and innovative models linking education, research, and health care services. The manuscript management system is completely online and includes a very quick and fair peer-review system. Visit http://www.dovepress.com/testimonials.php to read real quotes from published authors. 